\title{
PHYTOGEOGRAPHY OF THE MOSSES OF NEW SOUTH WALES
}

\author{
Helen P. Ramsay* \\ (Accepted for publication 29.3.1983)
}

\begin{abstract}
Ramsay, Helen P. (School of Botany, University of New South Wales, Kensington, Australia 2033) 1984. Phytogeography of the Mosses of New South Wales. Telopea 2(5): 535-547. - The data on distribution of mosses in New South Wales contained in a Census of New South Wales mosses (Ramsay 1984) are analysed in relation to intra- and extra-Australian distribution. Sixty-seven per cent of all moss families are represented in the State covering $801,600 \mathrm{sq} . \mathrm{km}$ with a wide variety of climate and topography. Some 527 species in 171 genera are present. Only 9 families that occur elsewhere in Australia are not represented. Seventy-seven per cent of the species are confined to the Southern Hemisphere; of these $55.5 \%$ are Australian 'endemics' of which $15.8 \%$ occur only in New South Wales. Less than half the species $(43 \%)$ occur also in New Zealand. A list of possible endemics, many of which are represented by a few collections only, and their distribution within the State, shows a concentration in the North and Central Coast. The preliminary nature of the survey is emphasised. It is likely that many of the species that are supposed endemics will be found to be more widespread and will be absorbed into synonymy when taxonomic revisions are made and more extensive field studies undertaken.
\end{abstract}

\section{INTRODUCTION}

The variety of forms in the interesting moss flora of New South Wales results from the diversity of habitat, climate and altitude in an area of $801,600 \mathrm{sq} . \mathrm{km}$ (Cameron 1980). New South Wales lies between $151^{\circ} \mathrm{E}$ and $141^{\circ} \mathrm{E}$ longitude and from $37^{\circ} \mathrm{S}$ to $29^{\circ} \mathrm{S}$ latitude. Temperate to subtropical regions with climatic variations dependent on temperature, rainfall and topography are present. The mean annual temperature ranges are greatest in the Southern Tablelands with the highest altitudes, and the Far West. Annual precipitation is highest along the North Coast $(>1500 \mathrm{~mm})$ and Southern Tablelands, decreasing from the coast westwards to the arid western plains ( $<260 \mathrm{~mm})$ (Fig. 3).

Anderson $(1961,1968)$ divided the State into four major ecogeographic divisions based on climate and topography: 1 . Coastal; 2 . Tablelands; 3 . Western Slopes; 4 . Western Plains. The characteristics of these regions, summarised from Anderson, are outlined briefly here so that correlations can be made between the distribution of mosses (Ramsay 1984a) and climatic factors. Jacobs \& Pickard (1981) used these divisions, with further modification, dividing the Western Plains into two regions - Western Plains and Far Western Plains. (For a map of New South Wales outlining these divisions see Figures 1 and 2.)

\section{ECOGEOGRAPHIC REGIONS}

\section{Coastal}

The coastal region, with a coastline of $1,900 \mathrm{~km}$, lies east of the Great Dividing Range. Average rainfall is greater than $635 \mathrm{~mm}$ per annum. Three subdivisions are recognised - South, Central and North.

The South Coast (SC) contains mainly Eucalyptus forests with some temperate rainforests in the gullies. The topography is undulating with rich soils.

*Also Honorary Research Associate, National Herbarium of New South Wales, Sydney. 


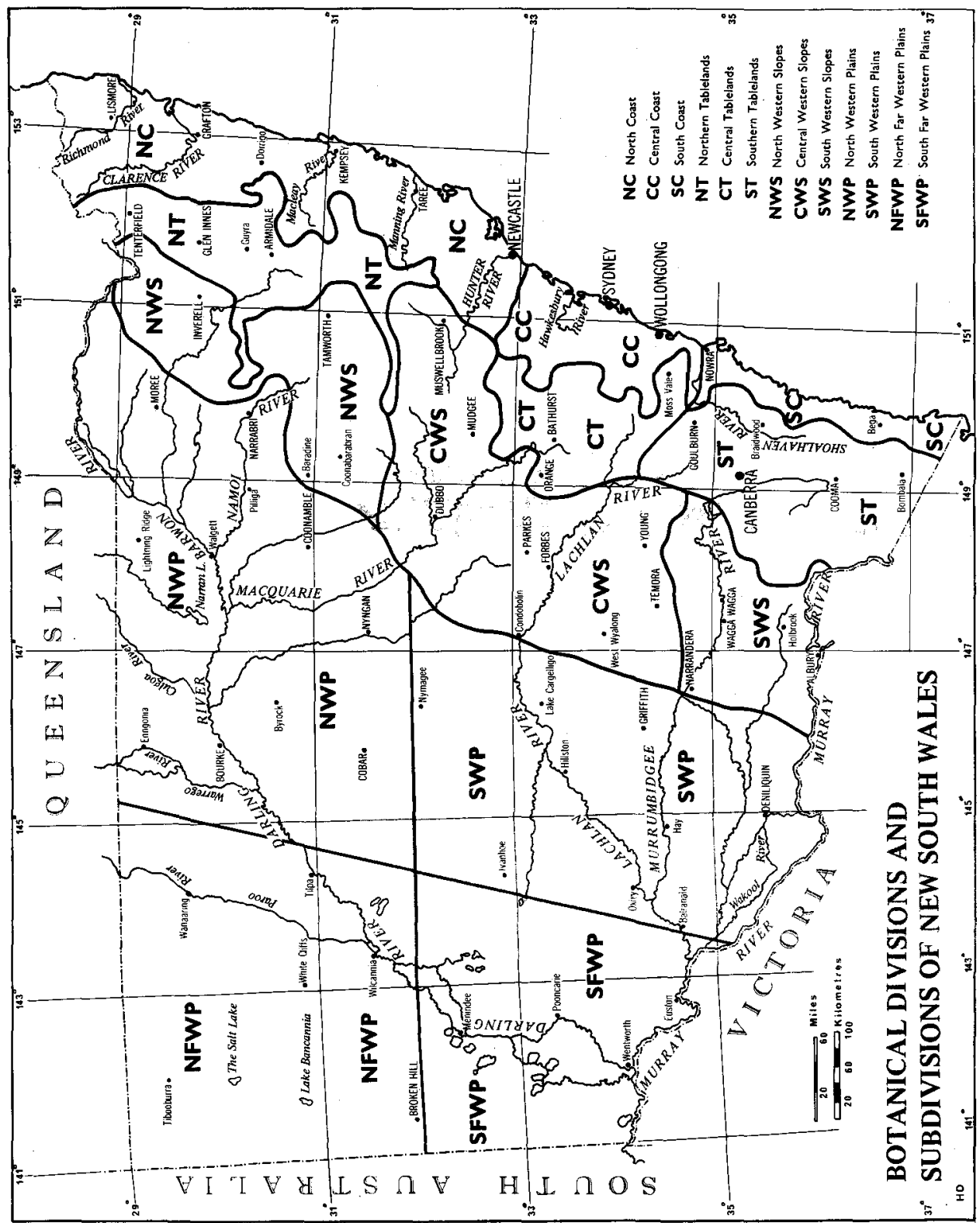

Fig. 1. Botanical divisions and subdivisions of New South Wales. (see Anderson, R.H. (1961). Introduction. Contr. New South Wales Natl. Herb., F1. Ser. Nos 1-18, pp. 1-15.)

Conditions such as soil, topography, altitude and rainfall are much more variable in the Central Coast (CC), which encompasses the Sydney Plains and the lower Blue Mountains, rising to an altitude of $900 \mathrm{~m}$. Rainfall varies from below the average mean $(1,168 \mathrm{~mm})$ to well above in the protected gullies of the lower Blue Mountains. 


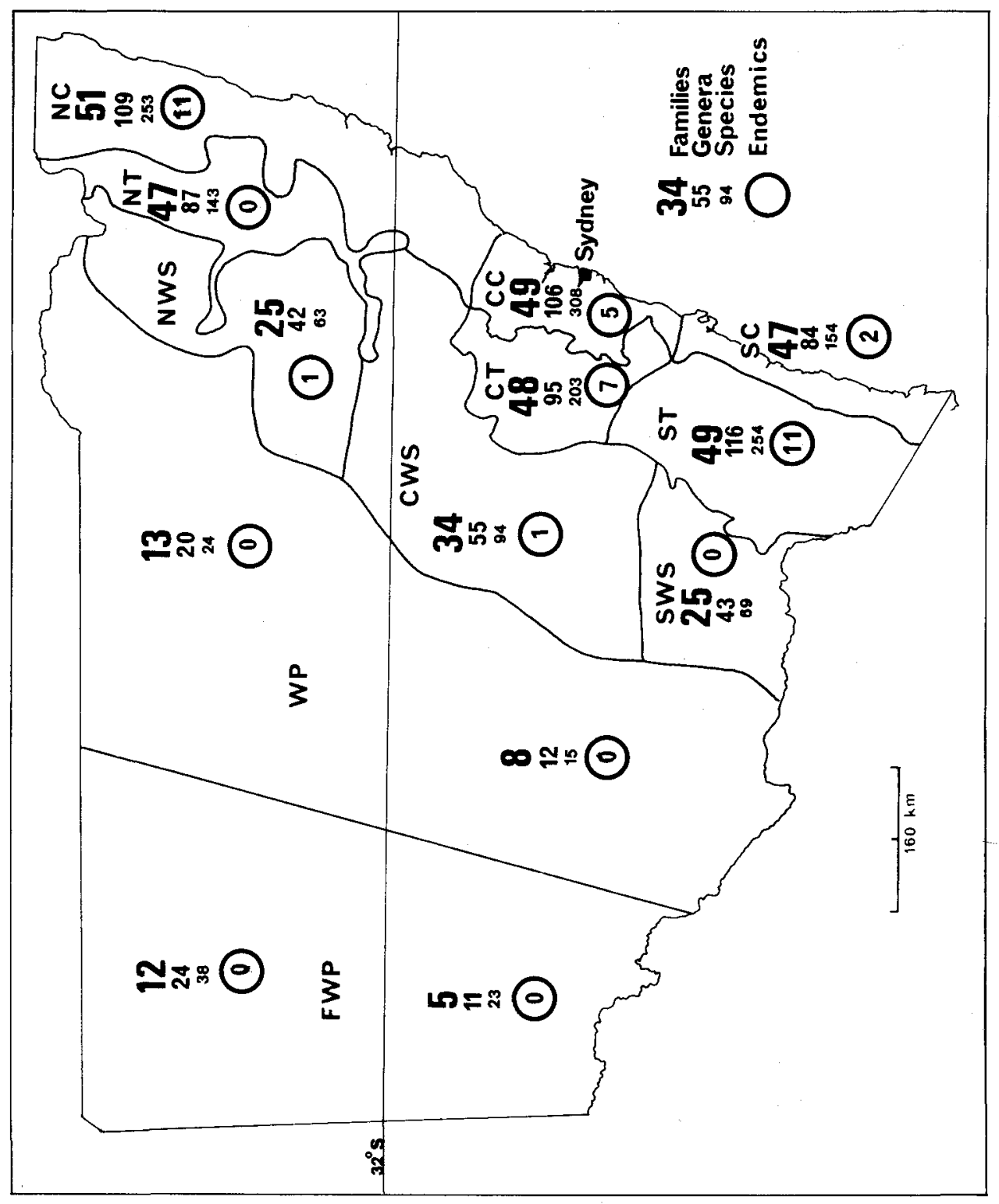

Fig. 2. Distribution of families, genera and species in New South Wales.

The North Coast (NC) becomes subtropical with higher rainfall (1,000 $1,700 \mathrm{~mm}$ ). Soil and forest types are much more varied in the north, including the eastern slopes of the Great Divide that rises to some $750-900 \mathrm{~m}$. The vascular plants of the area include species with mainly southern temperate distribution as well as northern subtropical elements. The region on the Queensland - New South Wales border, including both North Coast and Northern Tablelands, in which these elements occur together, is referred to as the Macleay - McPherson overlap by Burbidge (1960). 


\section{Tablelands}

The Tablelands can also be sub-divided into the Northern (NT), Central (CT) and Southern Tablelands (ST). The tablelands rise from a base altitude of $650 \mathrm{~m}$ in the south or $800 \mathrm{~m}$ in the north.

The Northern Tablelands is more uniform, consisting largely of plateaux up to $1,600 \mathrm{~m}$ high with granitic or basaltic soils and a rainfall from 800 to $900 \mathrm{~mm}$ per annum.

The Central Tablelands includes three different climatic areas: (a) The Bowral - Moss Vale area, altitude 650 - 850 m, has cold winters with heavy frosts, although snow occurs infrequently. Soils are derived from sandstone with some shale and basalt, while rainfall lies between 900 and $1,000 \mathrm{~mm}$ per annum and vegetation includes coastal tree species in the more sheltered valleys; (b) In the Blue Mountains, with altitudes up to $1,300 \mathrm{~m}$, soils are mainly from sandstone with a few basalt outcrops. The region consists of heavily dissected plateaux with vegetation varying considerably from heath on exposed uplands to temperate rainforests in gullies. Rainfall is more variable - between 900 and $1,400 \mathrm{~mm}$ per annum. Affinities of tree species are with the eastern forms; (c) Slightly west of the Blue Mountains is an extension of the Tablelands (Orange-Bathurst district) with lower rainfall, $600-900 \mathrm{~mm}$ per annum, and granitic and basaltic soils. It is characterised by having western tree species.

The Southern Tablelands vary greatly in altitude and climate since Australia's highest mountain ranges occur here. The Australian Capital Territory (A.C.T.), containing Australia's capital city, Canberra, falls within the Southern Tablelands. A more detailed analysis of the A.C.T. is given in Ramsay \& Streimann (1984). The Southern Tablelands may be subdivided into three areas - the eastern mountains, western mountains, and the central plateau connecting them. The western mountains include the Snowy Mountains with the tree-line at 1,920 m and its highest peaks exceeding $2,300 \mathrm{~m}$. Rainfall ranges from 990 to $1,500 \mathrm{~mm}$ per annum with some months of snow during winter. The eastern mountains are thickly forested, while the central plateau in the Monaro-Goulburn area has cold winters and hot summers with low rainfall -480 to $736 \mathrm{~mm}$ per annum. The low rainfall and heavy basaltic soils result in poor tree development in this section of the Southern Tablelands.

\section{Western Slopes}

The Western Slopes range in altitude down to $160 \mathrm{~m}$ in the south (SWS) and $270 \mathrm{~m}$ in the north (NWS). The northern, central (CWS) and southern areas of the slopes vary climatically with wide ranges in daily temperature and distribution of rainfall. In the north, rainfall is higher, up to $790 \mathrm{~mm}$ per annum, but mainly in summer. Rainfall up to $710 \mathrm{~mm}$ per annum is evenly distributed throughout the year in the central area, but occurs mainly in winter in the south with only $533 \mathrm{~mm}$ per annum where greater altitudinal variation occurs.

\section{Western Plains}

The Western Plains (NWP, SWP) have low average rainfall, $300-500 \mathrm{~mm}$ per annum, altitude below $160 \mathrm{~m}$ and extremes of temperature both daily and seasonally. In the Far Western Plains (FWP), precipitation is low in both the north (NFWP) and south (SFWP) with less than $260 \mathrm{~mm}$ per annum.

\section{DISTRIBUTION OF MOSSES IN NEW SOUTH WALES}

The distribution of mosses into the same subdivisions as Jacobs \& Pickard (1981), to enable correlation with data for the Census of New South Wales Plants, is presented by Ramsay (1984a). Using the distribution data provided by this moss census, an analysis of families, genera and species occurring in these regions of New South Wales is presented in Table 1 and Figure 2. 


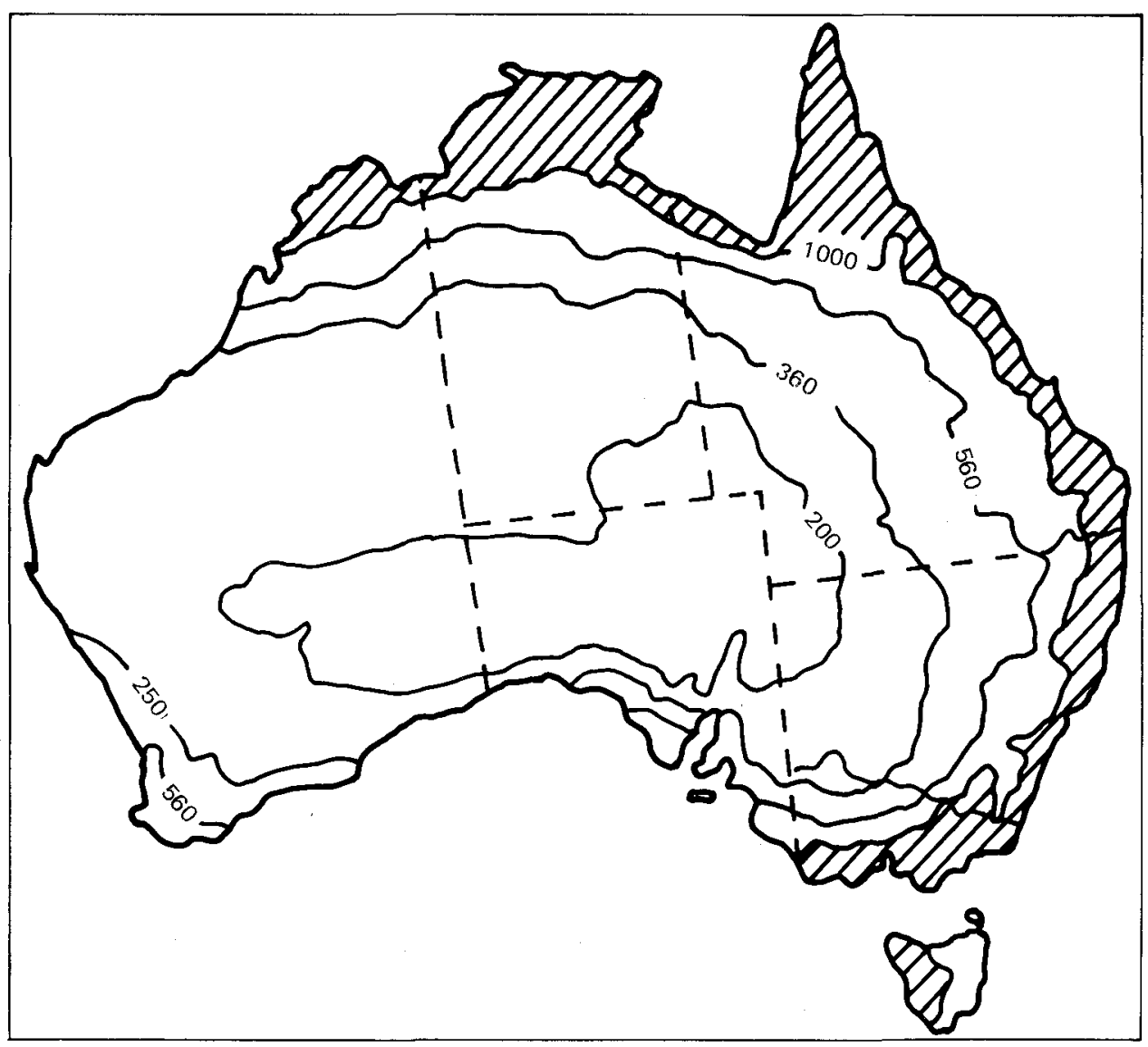

Fig. 3. Annual precipitation in Australia (mm). (Adapted from Fig. 10-7, p. 96 of Linacre \& Hobbs (1977). 'The Australian Climatic Environment'. (Wiley: New York.))

Knowledge of the distribution of mosses in Australia is not as advanced as that in the Northern Hemisphere such as North America (Steere 1965, 1976, 1979; Ireland et al. 1980; Schofield 1965, 1980) and Britain (Smith 1976); or South Africa (Sim 1926; Magill \& Schelpe 1979) and New Zealand (Sainsbury 1955; Martin 1951 ) in the Southern Hemisphere. Indeed there are few published analyses of moss distributions in Australia, but Herzog (1926) mentions some Australian species, Scott \& Stone (1976) include distributional data (by state) for many Australian species as well as lists of species with ecological preferences, while Catcheside (1980) divides South Australia into 21 areas noting the area(s) in which each of the 187 species described is located and also provides a more detailed analysis of geographical relationships of the species (Catcheside 1982). Some information is also available for individual families, e.g. Polytrichaceae (Smith 1972); Hypnodendraceae (Touw 1971); Hookeriaceae (Welch 1970); Bryaceae (Ochi 1970, 1972, 1973); Hypnaceae (Ando 1980); or genera such as Bryum (Mohamed 1979); Hypnum (Ando 1972); Mittythyridium (Nowak 1980); Atrichum (Nyholm 1971); Macrocoma (Vitt 1973); Dawsonia (van Zanten 1973), to mention a few, where worldwide revisions have been undertaken. In most cases, even when herbarium collections from Australia have been studied, the distribution has not been determined from recent field collections and the data will, therefore, be incomplete. 
Species in New Zealand with bipolar disjunct distributions are discussed by Schofield \& Crum (1972), and Schofield (1974, 1980), who include some Australian species in their treatments. Sixty-seven species (excluding those Schofield considers as introduced) are named as bipolar disjunctives (Schofield 1974). At least four of these - Drepanocladus uncinatus, Neckera pennata, Aulacomnium palustre and Plagiothecium denticulatum - occur in New South Wales. Van Zanten (1973, 1976, 1978), van Zanten \& Pócs (1982) have studied the pattern of distribution of some Southern Hemisphere species in relation to long- range dispersal to explain disjunctions.

\section{RELATIONSHIPS AND DISTRIBUTION PATTERNS}

As in other regions of the industrialised world, the influence of man has resulted in irretrievable loss of many natural habitats, including areas rich in mosses, in New South Wales particularly with the destruction of much of the coastal rainforests. Remnants of these forests that persist are often too exposed for the epiphytic flora, which once thrived, to survive. The introduction of agriculture too, particularly with the addition of fertilizers and cultivation, may have altered the soil structure in previously forested areas so that mosses that may have existed naturally could have been eliminated or replaced by 'weeds' or widespread invaders of disturbed soils. As so little attention has been given to bryophytes by collectors and herbaria in Australia during our history, much detailed information, as regards the effects of European settlement, has already been lost. The early collectors (i.e. late 1800 s, early 1900s) made a vital contribution as their specimens often represent the only examples from areas now denuded, e.g. specimens of Watts (see Ramsay 1980). There are also large gaps in our knowledge of mosses, indeed lower plants generally, as they have been included only rarely in publications such as ecological surveys or descriptions of vegetation types in Australia. Important exceptions in New South Wales are studies on the vegetation in the Snowy Mountains (Costin 1954, McVean 1969).

In spite of the many unsolved taxonomic problems in the moss flora of New South Wales and the very limited collecting in some areas, the information available gives some true indication of phytogeographical relationships of the species within the State.

The 56 families present contain 527 species in 171 genera. Sixty-seven percent of all moss families occur in New South Wales and these include all but 9 of the families that are found in Australia. Families not present in New South Wales are mainly tropical - Ephemeropsidaceae, Lepyrodontaceae, Myuriaceae, Pilotrichaceae, Trachypodaceae and Viridivelleraceae. The Pleurophascaceae and Leucomiaceae are southern temperate families. The family Archidiaceae was thought not to be represented in N.S.W., but one species has now been located (I.G. Stone, pers. comm.). Much work still remains to be done. In addition to the 527 species for which specimens have been located, literature records for 22 species for which no specimens have yet been located, and 81 invalid names reported as nomina nuda in Index Muscorum and Supplements (Wijk et al. 1959-1969; Crosby 1977, 1979; Crosby \& Bauer 1981) have yet to be clarified.

Only $23 \%$ of species have a distribution extending into the Northern Hemisphere, the remaining $77 \%$ being found only in the Southern Hemisphere. Of these latter, $55.5 \%$ are confined to Australia with $15.8 \%$ of these apparently restricted to New South Wales.

Sixty per cent of species have affinities with the temperate southern states Victoria, Tasmania, South Australia - while $40 \%$ are related to tropical Queensland species. Less than half the species, $43 \%$ only, are found also in New Zealand where the moss flora is more closely allied to Victorian and Tasmanian taxa. While species 'endemism' is high in the area, no genera or families occur in 
TABLE 1. FREQUENCY OF DISTRIBUTION OF MOSSES IN NEW SOUTH WALES (abbreviations for localities explained on p.459).

\begin{tabular}{lll}
\hline $\begin{array}{l}\text { SPECIES } \\
\% / \text { locality }\end{array}$ & $\begin{array}{l}\text { GENERA } \\
\text { \%/locality }\end{array}$ & $\begin{array}{l}\text { FAMILIES } \\
\% / \text { locality }\end{array}$ \\
\hline $58.0 \mathrm{CC}$ & $67.0 \mathrm{ST}$ & $91.0 \mathrm{NC}$ \\
$48.0 \mathrm{NC}, \mathrm{ST}$ & $63.4 \mathrm{NC}$ & $87.5 \mathrm{CC}, \mathrm{ST}$ \\
$38.3 \mathrm{CT}$ & $61.6 \mathrm{CC}$ & $85.7 \mathrm{CT}$ \\
$29.0 \mathrm{SC}$ & $55.2 \mathrm{CT}$ & $84.0 \mathrm{SC}, \mathrm{NT}$ \\
$27.0 \mathrm{NT}$ & $50.6 \mathrm{NT}$ & $60.7 \mathrm{CWS}$ \\
$18.0 \mathrm{CWS}$ & $48.8 \mathrm{SC}$ & $44.6 \mathrm{NWS}, \mathrm{SWS}$ \\
$13.0 \mathrm{SWS}$ & $32.0 \mathrm{CWS}$ & $23.2 \mathrm{NWP}$ \\
$12.0 \mathrm{NWS}$ & $25.0 \mathrm{SWS}$ & $21.4 \mathrm{NFWP}$ \\
$7.2 \mathrm{NFWP}$ & $24.4 \mathrm{NWS}$ & $14.3 \mathrm{SWP}$ \\
$4.5 \mathrm{SFWP}, \mathrm{NWP}$ & $14.0 \mathrm{NFWP}$ & $9.0 \mathrm{SFWP}$ \\
$2.8 \mathrm{SWP}$ & $11.6 \mathrm{NWP}$ & \\
& $7.0 \mathrm{SWP}$ & \\
& $6.4 \mathrm{SFWP}$ & $527^{*}$ \\
& Total number of species & 171 \\
& Total number of genera & 56 \\
\hline
\end{tabular}

* This total does not include 22 unsubstantiated records for described species nor 93 names in literature (nomina nuda) that include 23 for which no specimen has been located in Australian herbaria.

the New South Wales moss flora which do not have an extra-Australian distribution.

The summary of distribution of mosses within New South Wales (Fig. 2 and Table 1) shows the highest family, generic and species numbers in three subdivisions - Central Coast (CC), North Coast (NC) and Southern Tablelands (ST). Although quite dissimilar, these regions offer the greatest diversity of climate, soils and topography. All have variations in altitude, this being most significant in the Southern Tablelands. Lowest species, generic and family numbers occur, as expected, in low rainfall divisions (WP and FWP) with less than $260 \mathrm{~mm}$ per annum and little altitudinal or habitat variation. The paucity of mosses in these areas may be due, in part, to under-collection as many are ephemeral. This has been demonstrated by recent collections from I.G. Stone (pers. comm.) who has increased the number of species in the Far North Western Plains from 8 to 38, and genera from 8 to 24. Professor D.G. Catcheside (1980, pers. comm.) has also provided information on new species collections from the arid areas in New South Wales. Other subdivisions with high diversity of forms (CT, SC, NT) all contain either dissected plateaux or valleys in the foothills of ranges that provide a broad range of suitable habitats for bryophytes.

\section{NORTHERN HEMISPHERE DISJUNCTS}

In a discussion of mosses with bipolar distribution in North America, Schofield (1980) mentions the possibility that many were introduced unintentionally by man and thus occur widely in anthropogenic habitats. Of those listed as possibly introduced in North America (p.155), the following occur in New South Wales: Barbula unguiculata, Brachythecium albicans, Calliergonella (Acrocladium) cuspidata, Hypnum cupressiforme, Pottia truncata, Aulacomnium palustre, Drepanocladus fluitans, Polytrichum commune, Andreaea rupestris, Grimmia laevigata, G. pulvinata, Hedwigia ciliata, Pohlia cruda, Leptodon smithii, Neckera pennata, Ceratodon purpureus, Distichium capillaceum, Leptobryum 
pyriforme, Pohlia wahlenbergii. In addition, those species present in N.S.W. but not listed above that are common inhabitants of concrete walls in cities (Schofield 1980: 166) are Bryum argenteum, $B$. capillare, $B$. dichotomum, Tortula muralis, $T$. pagorum and T. papillosa. The latter two species of Tortula, however, are more commonly epiphytic on trees here, both on natives (Eucalyptus spp.) and exotics (Quercus, Populus, etc.). Since Tortula papillosa reproduces sexually only in Australasia, it is unlikely that it has been introduced here recently by man and indeed, little is known in Australia about which species have been introduced.

Other New South Wales species that have Northern Hemisphere affinities are several Sphagnum species, Weissia controversa, Funaria hygrometrica, Fissidens asplenioides, $F$. crassipes, Bryum muehlenbeckii, B. pachytheca, B. torquescens, Orthotrichum rupestre, Brachythecium rutabulum, B. rivulare, B. salebrosum, Plagiothecium denticulatum, Polytrichastrum (Polytrichum) alpinum and Polytrichum juniperinum.

Some species that are not so widespread as to be considered cosmopolitan occur in some regions of the Northern Hemisphere extending also to North and Central America or Asia, mainly SE Asia, e.g. Acaulon triquetrum (Eur, N Afr, N Amer), A. aloides (Eur, As, N Amer, Afr), Encalypta vulgaris (N Amer, As, Afr, NZ), Thamnobryum pandum (SE Asia), Glyphothecium sciuroides (SE Asia), Hampeella pallens (SE Asia), Meesia triquetra (N Hemis). But many species occurring in Australia and SE Asia often extend in range into Oceania or South America as well.

\section{SOUTHERN HEMISPHERE DISTRIBUTIONS}

The wider distributions of species found in N.S.W. fall into several categories:

(a) Subantarctic elements (Australia/New Zealand/South America)

(b) Malesian elements (N. Australia/Papua New Guinea/Indonesia/SE Asia)

(c) Oceania-Pacific elements (New Caledonia/Norfolk Island/Hawaii/New Hebrides/New Zealand and other Pacific Islands)

(d) African elements.

The relationships of New South Wales mosses to other southern continents tend to be either to Africa or South America and only infrequently to both, while only a small number of New South Wales species occur in the three continents. Those which do have a circum-austral range come from widely different families, e.g. Pottiaceae (Barbula australasiae, B. crinita), Sphagnaceae (Sphagnum australe), Ditrichaceae (Pleuridium nervosum), Dicranaceae (Dicranoloma billardieri), Bryaceae (Orthodontium lineare), Aulacomniaceae (Leptotheca gaudichaudii), Bartramiaceae (Breutelia pendula, Conostomum pentastichum), Phyllogoniaceae (Catagonium politum), Hookeriaceae (Achrophyllum dentatum), Brachytheciaceae (Brachythecium paradoxum) and Sematophyllaceae (Sematophyllum contiguum).

\section{(a) Subantarctic elements}

Species that extend across to South America but are not distributed through the Pacific Islands, except sometimes New Zealand, occupy many varied habitats, from ground mosses, e.g. Fissidens rigidulus, Polytrichadelphus magellanicus, to epiphytes growing close to the ground on tree trunks or on fallen logs and rocks, e.g. Dicranoloma menziesii, Weymouthia mollis. All come from moist habitats rather than arid ones and consist of one or two species in a wide range of families, e.g. Fissidentaceae, Dicranaceae, Seligeriaceae, Pottiaceae, Orthotrichaceae, Meteoriaceae, Hookeriaceae, Lembophyllaceae, Sematophyllaceae, Polytrichaceae.

\section{(b) Malesian elements}

Species in N.S.W. that have wider distributions to the northern tropical regions of Malesia (New Guinea, Indonesia and SE Asia) are found in families such as 
Orthotrichaceae, Ptychomniaceae, Phyllogoniaceae, Meteoriaceae, and Rhizogoniaceae and Spiridentaceae, but their numbers are small.

(c) Oceania-Pacific elements (including New Zealand)

There are some fourteen species that occur in New South Wales whose distribution is restricted to New Zealand and Oceania. Many of these are epiphytic and from subtropical or temperate rainforests, e.g. Holomitrium perichaetiale, Leucobryum candidum, Leptostomum macrocarpum, Hymenodon pilifer, Braithwaitea sulcata, Macromitrium spp., Papillaria spp., Wijkia extenuata. The few that extend further, e.g. to South America, occur in damp habitats, principally on creek banks, waterfalls, etc., e.g. Goniobryum subbasilare, Ptychomnion aciculare and Hypopterygium rotulatum.

The geographical range of mosses from Lord Howe Island (politically a part of New South Wales) is considered separately (pages 549-558). Its moss flora, as known at present, contains about $26 \%$ endemics; a further $37.5 \%$ are confined to Australia and New Zealand and 10\% extend across the Pacific to South America.

\section{(d) African elements}

Mosses that have an extra-New South Wales distribution extending westwards to Southern Africa (Magill \& Schelpe 1979) include a number of small ground mosses, e.g. Eccremidium exiguum, Bruchia brevipes, Bryobartramia novaevalesiae, Gigaspermum repens, whose distribution in Australia is primarily in arid habitats (Catcheside 1980, 1982). The 17 species that have such affinities come from widely different families, e.g. Fissidentaceae (Fissidens tenellus), Dicranaceae (Campylopus bicolor), Polytrichaceae (Psilopilum australe).

\section{ENDEMISM}

About 90 of the species are apparently limited in distribution to New South Wales. This number is probably an exaggerated estimate of 'endemics' since it is likely that some species will be reduced to synonymy once Australia-wide or worldwide revisions of the genera in which these species occur have been undertaken. The names are arranged in family sequence from Census of New South Wales mosses (Ramsay 1984a) in Table 2. Quite a number of species previously considered endemic have been absorbed into synonymy already as predicted by Watts (see Ramsay 1980).

From Figure 1 and Table 2 it is clear that the subdivisions in New South Wales with the greatest numbers of such species endemic to an area are the North Coast (11), Central Coast (5) and Southern Tablelands (11). Some of the possible endemics have a much wider intrastate distribution. In all, 35 of these so-called 'endemics' are found in the North Coast, 26 in the Central Coast and 19 in the Southern Tablelands (Table 2). Although the North Coast and Southern Tablelands may be regions where, because of climatic or geological disturbance, their past history has provided the geographical isolation necessary for endemism, the more likely explanation is that these areas or species have not been investigated in enough detail.

We know nothing of the origins or past history of bryophytes in Australia, the effects of glaciation, where this occurred, fire frequency or the dispersal pathways followed during climatic changes. In particular, the North Coast endemics need careful comparison with Queensland species before any clear understanding of the significance or extent of endemism can be assessed. For example, the apparent disjunct distribution of two endemics, Pleuridium brachycaulon (Central Coast, North Western Slopes) and Astomum novae-valesiae (Central Coast, Southern Tablelands), may be due to paucity of collecting as they are both small ground mosses. 
TABLE 2. SPECIES APPARENTLY ENDEMIC TO N.S.W. \& THEIR DISTRIBUTION (rare $=\leq 3$ collections) [List excludes LHI endemics recorded in Ramsay 1984c]

\begin{tabular}{|c|c|}
\hline SPECIES & $\begin{array}{l}\text { DISTRIBUTION } \\
\text { (for key to abbreviations see } \\
\text { p.459) }\end{array}$ \\
\hline $\begin{array}{l}\text { ANDREAEACEAE } \\
\text { Andreaea tenera C. Muell. }\end{array}$ & CT \\
\hline $\begin{array}{l}\text { FISSIDENTACEAE } \\
\text { Fissidens aristatus Broth. } \\
\text { F. bryoidioides Broth. } \\
\text { F. forsythii Broth. } \\
\text { F. homomallulus C. Muell. ex Dix. } \\
\text { F. montecollii Broth. \& Watts } \\
\text { F. sordidevirens Broth. } \\
\text { F. wattsii Broth. }\end{array}$ & $\begin{array}{l}\mathrm{C} \\
\mathrm{CC}(\text { rare }) \\
\mathrm{NC}, \mathrm{NT}(\text { rare in both) } \\
\mathrm{NC}, \mathrm{CC} \\
\mathrm{NC} \\
\mathrm{NC}, \mathrm{CC} \\
\mathrm{LHI}, \mathrm{CC}\end{array}$ \\
\hline $\begin{array}{l}\text { DITRICHACEAE } \\
\text { Pleuridium curvisetum Stone } \\
\text { P. viride(C. Muell.) Kindb. }\end{array}$ & $\begin{array}{l}\text { ST } \\
\text { CC }\end{array}$ \\
\hline $\begin{array}{l}\text { DICRANACEAE } \\
\text { Campylopis denticuspis Broth. var. lutescens Broth. } \\
\text { C. perauriculatus Broth. } \\
\text { Dicranella apophysatula (C. Muell.) Broth. }\end{array}$ & $\begin{array}{l}\mathrm{CC} \\
\mathrm{NC}, \mathrm{SC} \\
\mathrm{NC}(\text { rare })\end{array}$ \\
\hline $\begin{array}{l}\text { LEUCOBRYACEAE } \\
\text { Leucobryum subchlorophyllosum Hampe } \\
\text { L. turgidulum C. Muell. }\end{array}$ & $\begin{array}{l}\mathrm{NC} \text { (rare) } \\
\mathrm{CT} \text { (rare) }\end{array}$ \\
\hline $\begin{array}{l}\text { CALYMPERACEAE } \\
\text { Calymperopsis wattsii (Broth.) Fleisch. }\end{array}$ & $\mathrm{NC}$ \\
\hline $\begin{array}{l}\text { POTTIACEAE } \\
\text { Barbula speirostega C. Muell. } \\
\text { Didymodon wildii (Broth.) Broth. } \\
\text { Hymenostomum olivaceum C. Muell. ex Geh. } \\
\text { H. sullivanii C. Muell. ex Geh. } \\
\text { Tetrapterum sullivanii (C. Muell.) Broth. } \\
\text { Tortella novae-valesia Broth. } \\
\text { Tortula evanescens Broth. } \\
\text { T. panduraefolia (C. Muell. \& Hampe) Broth. } \\
\text { T. readeri (C. Muell.) Broth. } \\
\text { T. streptopogoniacea (C. Muell.) Broth. } \\
\text { T. subbrunnea Broth. \& Watts } \\
\text { T. vesiculosa (C. Muell.) Broth. } \\
\text { Trichostomum aristatulum Broth. } \\
\text { Weissia novae-valesiae (Broth. ex Roth) Stone } \\
\text { W. perpusilla Stone }\end{array}$ & $\begin{array}{l}\text { CT (rare) } \\
\text { NWP (rare) } \\
\text { NC, CC, NT, CT, NWS } \\
\text { NT, CWS (rare in both) } \\
\text { NC } \\
\text { NC, CC (rare in both) } \\
\text { CWS (rare) } \\
\text { CC, T, NWS, CWS, NWP, } \\
\text { (rare in all but CC) } \\
\text { NWS (rare) } \\
\text { NC (rare), WS (rare), CT } \\
\text { ST(rare) } \\
\text { NC, T (rare in ST), CWS, SWS } \\
\text { CC, ST (rare) } \\
\text { CC }\end{array}$ \\
\hline $\begin{array}{l}\text { GRIMMIACEAE } \\
\quad \text { Racomitrium pseudo-patens (C. Muell.) Par. }\end{array}$ & ST \\
\hline $\begin{array}{l}\text { FUNARIACEAE } \\
\text { Funaria sphaerocarpa C. Muell. } \\
\text { F. squarrifolia Broth. } \\
\text { Physcomitrium integrifolium Hampe \& C. Muell. }\end{array}$ & $\begin{array}{l}\text { NC, CT, ST, LHI } \\
\text { NC } \\
\text { ST (rare) }\end{array}$ \\
\hline $\begin{array}{l}\text { SPLACHNACEAE } \\
\text { Splachnobryum wattsii Broth. } \\
\text { Tayloria maidenii Broth. }\end{array}$ & $\begin{array}{l}\text { CC } \\
\text { ST, NWS }\end{array}$ \\
\hline $\begin{array}{l}\text { BRYACEAE } \\
\text { Bryum aeruginosum C. Muell. } \\
\text { B. bateae C. Muell. } \\
\text { B. calodictyon Broth. } \\
\text { B. plumosum Dozy \& Molk. } \\
\text { B. subapiculatum Hampe } \\
\text { Mielichhoferia turgens Broth. } \\
\text { Pohlia austro-carnea Broth. }\end{array}$ & $\begin{array}{l}\text { CC } \\
\text { SC } \\
\text { CWS } \\
\text { NC } \\
\text { ST } \\
\text { CWS, SWS (rare) } \\
\text { CC (rare) }\end{array}$ \\
\hline $\begin{array}{l}\text { BARTRAMIACEAE } \\
\text { Bartramia timmioides C. Muell. } \\
\text { Breutellia pseudo-philonotis (C. Muell.) Watts \& Whitel. } \\
\text { Philonotis austro-falcata Broth. \& Watts } \\
\text { P. pseudomollis (C. Muell.) Jaeg. }\end{array}$ & $\begin{array}{l}\mathrm{CC} \text { (rare) } \\
\mathrm{CC} \\
\mathrm{ST} \text { (rare) } \\
\mathrm{NC}, \mathrm{CC}, \mathrm{CWS}\end{array}$ \\
\hline
\end{tabular}


TABLE 2 (cont'd)

PTYCHOMITRIACEAE

Ptychomitrium laxifolium (C. Muell.) Par.

ORTHOTRICHACEAE

Schlotheimia funiformis Tayl. ex Dix.

METEORIACEAE

Pilotrichella dimorpha (C.Muell.) Jaeg.

LEMBOPHYLLACEAE

Camptochaete excavata (Tayl.) Jaeg.

C. schlosseri (Sendtn.) Broth. ex Par.

HOOKERIACEAE

Achrophyllum wattsil (Broth.) Vitt \& Crosby

Distichophyllum minutifolium C. Muell.

D. subminutifolium (Broth. \& Geh.) Fleisch.

D. whiteleggeanum C. Muell.

FABRONIACEAE

Anacamptodon wattsii Broth.

Helicontiadelphus australiensis Dix.

AMBLYSTEGIACEAE

Amblystegium austro-hygrophilum Broth.

Calliergon stramineum (Brid.) Kindb.

Cratoneuropsis subrelaxa (Broth.) Broth.

Drepanocladus fontinaloides (Hampe) Broth. ex Par.

BRACHYTHECIACEAE

Brachythecium novae-valesiae Geh.

Rhynchostegium straminioides (Sauerb.) Wijk \& Marg.

PLAGIOTHECIACEAE

Plagiothecium novae-valesiae Broth.

SEMATOPHYLLACEAE

Sematophyllum luciduloides (Dix.) Mitt.

$S$ wattsii (Par.) Broth.

Wijkia crossii (Broth.) Crum

HYPNACEAE

Ectropothecium condensatum Broth. \& Watts

E. sydneyense Dix.

Isoptervgium amblyocarpum (Hampe) Broth.

I. amoenum Broth.

I. arachnoideum Broth.

I. latifolium Broth.

I. pseudo-subulatum (C. Muell.) Par.

I. subarachnoideum Broth.

BUXBAUMIACEAE

Buxbaumia colyerae Burges

POLYTRICHACEAE

Pogonatum brachypodium (C. Muell.) Watts \& Whitel.

Polytrichum brachypelma C. Muell.

P. cataractarum C. Muell.

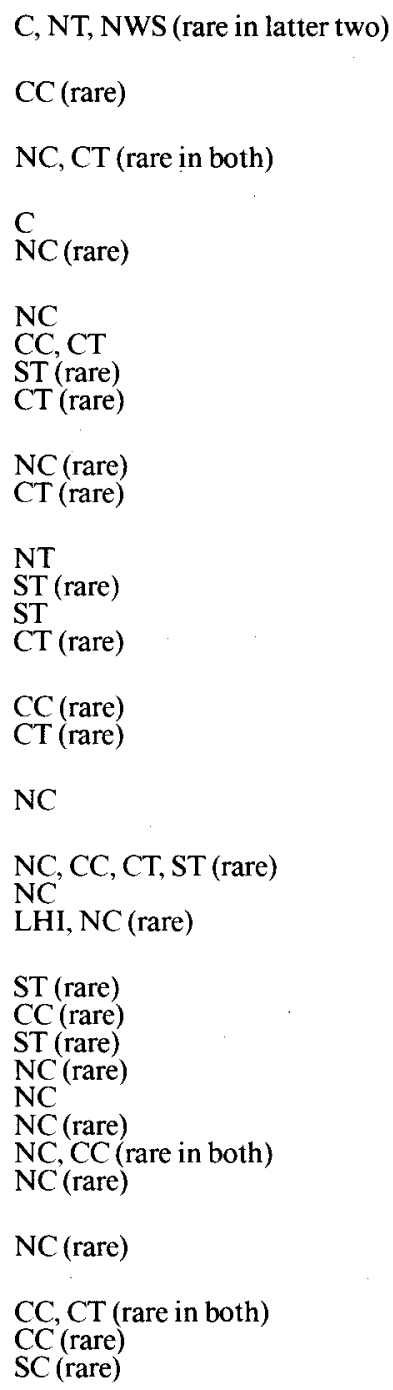

\section{CONCLUSION}

Even such a preliminary analysis as this has been able to show some interesting features of the wider distribution of New South Wales mosses, as well as their intrastate dispersion. In considering the latter, several factors need to be taken into account in each area under consideration, e.g. its size, ecogeographic features and the extent of collecting carried out, as a measure of reliability of distribution data. It is important that specific areas should be more intensively studied, as has been done for the Australian Capital Territory (Ramsay \& Streimann 1984). Some progress is being made towards inclusion of moss species in vegetation surveys within some National Parks (G. Harden, pers. comm.; I.G. Stone, pers. comm.). This should continue but is dependent on access to trained bryologists for identification of specimens. 
Other areas of study that would be valuable for detailed analysis are the alpine regions of New South Wales and Victoria, and the MacPherson-Macleay overlap (Burbidge 1960) on the border of New South Wales and Queensland. This district contains some of the few remaining areas of rainforest in Australia and has been considered of great botanical interest. The mix of two types of rainforest - that with elements related to the Indo-Malayan flora and the other with Antarctic elements - in this border region provides a unique opportunity for study (Hitchcock 1979). Recent analysis of the Australian flora and its origins has led Webb \& Tracey (1980) to suggest that re-interpretation is needed. They put forward the hypothesis that Australia contains the ancient elements of tropical angiosperm species now present in the Indo-Malayan region, rather than more recent immigrants as previously thought. Australia is indeed an ancient refuge for primitive angiosperms as evidenced by recent pollen studies (Martin 1978). The border region of New South Wales and Queensland is an area where perhaps important information on the origins of some tropical bryophytes may also be found.

The southern alpine and New South Wales-Queensland border regions contain both endemics and species whose wider distribution patterns are interesting. With taxonomic assessment of species with limited distributions and intensive collecting in regions of particular interest, it may be feasible within the foreseeable future to begin mapping distribution in detail for some species, as well as determining species diversity within defined geographical areas - as large as regions used in this study or in smaller more discrete localities as in the Australian Capital Territory.

\section{REFERENCES*}

Anderson, R.H. (1961). Introduction. Contr. New South Wales Natl. Herb., F1. Ser. Nos. 1-8: 1-15.

Anderson, R.H. (1968). 'The Trees of New South Wales.' (Govt Printer: Sydney.) Edn 4.

Burbidge, N.T. (1960). The phytogeography of the Australian region. Austral. J. Bot. 8(2): $75-211$.

Cameron, R.J. (1980). 'Pocket Year Book of Australia.' No. 65. (Australian Bureau of Statistics: Canberra.)

Du Reitz, G.E. (1940). Problems of bipolar plant distribution. Acta Phytogeogr. Suec. 13: 215-282.

Herzog, T. (1926). 'Geographie der Moose.' (Gustav Fischer: Jena.)

Hitchock, P. (1979). Rainforest types. Parks \& Wildlife 2(1): 32-46.

Ireland, R.R., Bird, C.D., Brassard, G.R., Schofield, W.B. \& Vitt, D.H. (1980). Checklist of the mosses of Canada. Natl. Mus. Canada Publ. Bot. 8: $1-75$.

Linacre, E. \& Hobbs, J. (1977). 'The Australian Climatic Environment.' (Wiley: New York.)

Martin, H. (1978). Evolution of the Australian flora and vegetation through the Tertiary: evidence from pollen. Alcheringa 2: 181-202.

Martin, W. (1958). A survey of moss distribution in New Zealand. Bryologist 61: 105-115.

Schofield, W.B. (1965). Correlations between the moss floras of Japan and British Columbia, Canada. J. Hattori Bot. Lab. 28: 17-42.

Schofield, W.B. (1980). The phytogeography of the mosses of North America (North of Mexico). In Taylor, R.J. and A.E. Leviton (eds), 'The Mosses of North America.' (Pacific Division American Association for the Advancement of Science: San Francisco.) pp. 131-170.

* For a full reference list see Ramsay, H.P. (1984), Census of New South Wales mosses, Telopea 2(5): 455-533. 
Steere, W.C. (1965). The boreal bryophyte flora as affected by Quaternary Glaciation. In Wright, A.E. and D.G. Frey (eds), 'The Quaternary of the United States.' (Princeton Univ. Press: Princeton.) pp. 485-495.

Steere, W.C. (1976). Ecology, phytogeography and floristics of Arctic Alaskan bryophytes. J. Hattori Bot. Lab. 41: 47-72.

Steere, W.C. (1979). Taxonomy and phytogeography of bryophytes in Boreal and Arctic North America. In Clarke, G.C.S. and J.G. Duckett, 'Bryophyte Systematics.' (Academic Press: London.) Vol 14, pp. 123-158.

Webb, L. \& Tracey, J.G. (1980). Australian rainforests and patterns of change. In Keast, A. (ed.), 'Ecological Biogeography of Australia.' (W. Junk: The Hague.) Edn 2.

Zanten, B.O. van (1976). Preliminary report on germination experiments designed to estimate the survival chances of moss spores during aerial transoceanic long-range dispersal in the Southern Hemisphere with particular reference to New Zealand. J. Hattori Bot. Lab. 41: 133-140. 